\title{
AKHISM VALUES AND GLOBAL COMPACT PRINCIPLES: AN ANALYSIS ON POINTS OF OVERLAP AND DISCRIMINATION
}

\author{
Hasan TUTAR ${ }^{\mathrm{a}}$
}

\begin{abstract}
Öz
Values are the criteria that guide people's attitudes and behaviors. People need values as a criterion for their attitudes and behaviors in their business and private lives. People are social beings, and value is produced due to relations with people and even with nature. Attitudes and behaviors about what is going on around him and how he evaluates them give people work and life values. When a person reacts to the events around him, he evaluates them and assigns a value to them. Value is the primary standard and criteria that affect social and individual life and enable to make judgments such as sound, bad, right, wrong, right, and wrong. At this point, value functions as a criterion in determining the distinction between "what is and ought to be." Value functions as meaning systems that people give to any event or phenomenon. While values are sometimes expressed as beliefs about people's behavior according to their preferences, sometimes they can be seen as "preference criteria" or "living standards." The primary purpose of this research is to determine the points of overlap and divergence by comparing the Ahi-order values that emerged under the futuwwa and the Global Compact presented as a set of global values today. Since the research is based on comparing two different value systems, the content analysis technique, a qualitative method, will be used. For this purpose, the content analysis of the texts reflecting the fundamental values of the two value systems will be made, and the starting point of the global compact values system will be analyzed comparatively.
\end{abstract}

Anahtar kelimeler: Psychology of Religion, Social values, Akhism, Ahi Evran, Global Compact, work values, social capital.

$$
\text { 䊏淡 }
$$

AHİLİK DEĞERLERİ VE GLOBAL COMPACT İLKELERİ: ÖRTÜŞME VE AYRIŞMA NOKTALARI ÜZERINNE BİR ÇÖZÜMLEME

\footnotetext{
a Prof. Dr., Abant İzzet Baysal Üniversitesi, hasantutar@ibu.edu.tr
} 
Değerler insanların tutum ve davranışlarına rehberlik eden ölçütlerdir. İnsanlar iş ve özel yaşamlarında tutum ve davranışlarına ölçüt olması bakımından değerlere ihtiyaç duyarlar. İnsanlar sosyal bir varlıktır ve değer insanlarla hatta tüm doğayla kurduğu ilişkiler sonucunda üretir. Çevresinde olup bitenler hakkındaki tutum ve davranışları ve onları değerlendirme biçimi insana iş ve yaşam değerleri kazandırır. İnsan çevresindeki olaylara tepki gösterdiğinde, onlar üzerinde birtakım değerlendirmelerde bulunur ve onlara bir değer atfeder. Değer, insanın herhangi bir olaya veya olguya verdiği anlam dizgeleri olarak işlev görür. Değerler kimi zaman insanın tercihine göre davranmasına ilişkin bir inanç olarak ifade edilirken, kimi zaman da "tercih ölçütleri" ya da "yaşam standartları" olarak görülebilir. $\mathrm{Bu}$ araştırmanın temel amacı fütüvvet geleneğinin etkisiyle ortaya çıkmış olan Ahilik değerleri ile bugün küresel değerler seti olarak sunulan Global Compact arasında karşılaştırma yaparak örtüşme ve ayrışa noktalarını belirlemektir. Araştırma iki farklı değerler dizgesinin karşılaştırılmasını esas aldığı için araştırmada nitel bir yöntem olan içerik çözümleme tekniğinden yararlanılacaktır. Bu amaçla araştırmada iki değerler dizgesinin temel değerlerini yansıtan metinlerin içerik çözümlemesi yapılarak ahilik değerleri ile global compact değerler dizgesinin hareket noktası karşılaştırmalı olarak analiz edilecektir.

[Geniş Öz, makalenin sonunda yer almaktadır.]

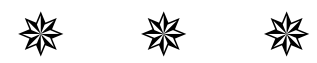

\section{Introduction}

Whenever values are mentioned, the first thing that comes to mind is the individual and his/her work and private life. For this reason, values are the norm-setting principles that regulate one's business and private life, Kağıtçıbaşı, 1980: 21). When a person or society aims for something for himself, he searches for the conditions to reach it and creates belief, norm and value. He thinks that these beliefs and values will help him reach his goal. This is a probabilistic belief and devoid of any objective basis, rather than having a firm judgment on a subject. The institutionalization of beliefs and values depends on their spread to the social plane (Milman, \& Kiparsky, 2020; Maaranen et al., 2019; Beck et al., 2018). In this context, ahi-order values are essential in the socialization and institutionalization of the values that shape social, economic, and cultural life. As of the period of Ahi-order values, in the words of Kant, it played an essential role in contributing to the institutionalization of the moral law (Aydın, 1991: 52). In Akhism, there is an obligation to follow the "moral law" in any social, economic, and cultural activity. The primary purpose of such a belief is to live a life of honesty, truthfulness, justice, nobility, trust, and virtue. The primary purpose of these 
principles is to lead a life based on morality and faith in society. The main goal of the phenomenon of "religion" is institutionalizing good morals, which is precisely what Ahilizm tried to do.

Values are related to a person's attitude towards the object in his attitudes, behaviors, goals, and actions. If a person tries to be "honest," he sees honesty as a "value." In this respect, values are the organizing criteria of one's business and private life (Joy et al., 2021; Ismail and Omari, 2017; Pickles et al., 2017). The primary purpose of the Ahi organization is to build a civilization based on human resources by gaining knowledge, skills, and individual and social values through education. This study aims to examine the ahi-order values comparatively with the value system of "global compact" (https://ungc.bilgi.edu.tr), which is intended to be implemented by the United Nations all over the world. The primary purpose is to emphasize that societies can create a solid civilization by getting more prosperous and developing. In this way, it is to draw attention to the fact that honesty in commercial life, which is one of the issues that the society frequently complains about, and all kinds of corruption and corruption in the society can be prevented by building a life based on certain principles. In the most general terms, it draws attention to the importance of living a valuebased life in individual, social and cultural life.

The primary purpose of the Akhism values is to create a human resource infrastructure for society's social, economic, and cultural development. With the awareness that there can be no development despite the human being, the main element of social development, Akhism has acted from the principles of futuwwa (Turkish-Islamic guild) tradition) by prioritizing human education (Ünsür, 2020; Ozata and Sener, 2019). The primary purpose of education in the system of Akhism is to provide a permanent and imprinted behavioral change in people. Another aim is to transfer the said behavior change to future generations through acculturation. The primary purpose of Akhism values is to increase the knowledge and skills of the person on the one hand and enable him to become active subjects with a rapid socialization process on the other hand. Because, in the understanding of Akhism, the economic, social, and cultural development of the society is a simple process of enrichment and physical reproduction and a process of development, progress, and armament with a system of values.

The main goal of Ahi-order values is economic development and social and cultural development (Özata and Şener, 2018). On the other hand, Global 
Compact aims to create a system of values within the 10 Principles determined by the United Nations Organization and spread only working values worldwide. For this purpose, the primary responsibilities of the business world in the fields of human rights, labor standards, environment, and anti-corruption have been determined in 10 principles. The 10 Principles of the United Nations Global Compact are based on the United Nations declarations, which are universally accepted and based on secular concerns (www.unglobalcompact.org). It can be argued that it would be essential and functional to make a comparative analysis between the ahiorder values and the global compact values, with the richness of its principles and content, over a thousand years in between. The research will also make an essential contribution to filling the gap in the literature in this direction. Accordingly, the research aims to answer the fundamental question of "What are the divergence and overlapping points of the United Nations Global Compact and Akhism values."

\section{A. The Concept of Value and Related Concepts}

Values are culturally defined and coded standards to guide social life. The concept of value Allport is a belief about a person acting according to his choice; Williams, on the other hand, defined it as preference criteria or standards (Fischer and Hänze, 2020; Büssing et al., 2019). According to Hofstede, values tend to prefer certain situations over others. Güngör defined value as the belief that something is desirable or acceptable or unacceptable (Güngör, 1998: 27). On the other hand, Rokeach defines value as the persistent belief that particular behavior and purpose of existence is personally and socially preferable to its opposites (Rokeach, 1973:5). From the definitions, it is understood that value is a measure of behavior that affects a person's choice in terms of goals and means in his behavior. Values are criteria that individuals have gained continuity through cultural interaction since birth and define beliefs, events, facts, and people (Nevitte et al., 2021; Littman et al., 2021). Values are socially shared, adopted, and agreed on rules and rules. They are the systems adopted individually and reveal individual differences. With a broad definition, values are generalized moral principles, adopted objective standards, and functional beliefs.

Human beings live in the physical world as living beings and in the metaphysical world as human beings. The metaphysical world in which man lives in the world of morals and values. It is impossible to talk about any attitude or behavior unrelated to values (Mengüşoğlu, 1983: 32; Shobeiri, 2018). In particular, moral philosophers were interested in the concept of 
value, the structure of values, the subjectivity or objectivity of values. Idealists; defined the universe with the concepts of "infinite" and "universal," and in parallel, they saw values as unchanging and objective principles applicable to all people. Realists have emphasized that people can develop their values according to nature and social laws, and since these laws are universal and eternal, values should be arranged in the form of general and universal criteria following these laws. Utilitarians do not accept the universality of values. According to them, values change depending on different environments and conditions, time, place, and situations. That is why, according to utilitarians, values are relative. For them, the value of values derives from its ability to bring benefits. In terms of utilitarians, things that contribute to people's personal and social development are valuable, while things that prevent their development are worthless (Sadegül, 2003; Nebot, 2021; Zhao, 2021). The utilitarian view of value, which holds that the value of something depends on its ability to provide happiness for the most significant number of people; It is not accepted by the objectivist understanding of value, which argues that values such as goodness, beauty, and truth exist independently of people and corresponds to objective realities that do not change from person to person, culture to culture. Those who adopt the objectivist value approach argue that a concept such as "value" is too general and universal to be reduced to individual benefit (Cevizci, 2000).

Apart from the discussions on the value categories of philosophy schools, human beings express a whole with their physical and psychological characteristics. Human beings live in a world consisting of beliefs, attitudes, thoughts, and values with their psychological characteristics. Values and beliefs cannot be handled independently of the person, and his/her behaviors show that they affect individual life, work, and social life (McCarty and Shrum 1994: 58). There are values behind all attitudes and behaviors of a person. His values guide his attitudes and behaviors towards work. The fact that values are one of the main motives that determine people's behavior shows that different value codes can explain individual differences in human behavior. Attitudes are in the depths of attitudes' behaviors, beliefs, and values (Kilic et al., 2021). Therefore, values cannot be considered independently of ethical norms and beliefs. A significant problem here is the problem of the source of the values. The source of values are sometimes ethical codes, sometimes belief systems, and sometimes social norms.

It can be argued that the primary basis of values is ethics, without distinguishing between ethics or morality. The concept of ethics, derived 
from the Greek "ethos" meaning character, temperament, tradition, refers to the ideal and the abstract. Ethics as a system of norms is a sub-branch of philosophy, a philosophical activity that explores the essence and foundations of morality. Ethics, which analyzes the status of moral judgments, also focuses on what moral attitudes should be (Akarsu, 1998: 74; Aydın, 2003: 15). Ethics gain functionality in the lives of individuals or societies in terms of the characteristics required to be a good person and the rules that determine and limit the individual's behavior, which is also valid for values. Every value is formed within the framework of the society's and the individual's ethical understanding of that value.

As in individual and social life, it is not correct to separate business values and business ethics in business life. Especially when it is considered in the context of ahi-order, being hardworking, honest, and establishing good relations with other employees are the requirements of both business ethics and business ethics. Professional ethics are the rules that show a particular profession's "right" and "wrong" behaviors. Honesty in relationships, keeping one's word, being respectful to people, acting reasonably, and opposing injustices are the requirements of both professional ethics and work values. Behaviors formed within beliefs, values, and rights, duties, and responsibilities regarding work are shaped according to work and professional ethics (Sison, 2018). Therefore, there are both beliefs and values based on professional ethics. Since business ethics is the general name of the common truth and common good in the business environment, distinguishing between values and morality may be conceptual or theoretical, but the distinction is not easy in practice.

Values and beliefs are often considered together, and there is a close relationship between them. Based on values, there is either purely religious faith based on the understanding of duty or institutional faith based on revelation, or moral faith, theoretical faith or pragmatic faith, which are different manifestations of these, as Kant expresses, depending on the place (Tanriverdi, 2012: 91). Values that regulate interpersonal relations and are based on belief and determine a person's relationship with property affect people's attitudes and behaviors. Rokeach, who has made essential studies on values, sees value as one of the types of belief (Robles, 2019). Güngör (1998: 28), on the other hand, sees values as deep beliefs. According to him, values as a specific type of belief are a higher mental organization than belief. It is higher than belief because value includes not just one but many organized beliefs. For example, benevolence is a value, and many beliefs are hidden under this value. Many beliefs contribute to the belief underlying 
doing good to someone, such as the belief that helping people is socially sound, the belief that kindness will give people peace of mind, the belief that benevolence will bring well-being, and the belief that God loves benefactors.

Values are often confused with the concept of "belief" because they are general beliefs that are shared, adopted, approved, and agreed upon individually and socially. Values provide "criteria" or "standards," while beliefs function more as "principals." Despite the closeness of meaning, the concept of "value" is different from the concept of "belief" and functions as a separate factor and other elements that make up the culture of the society, the attitudes, and behaviors of the person. For beliefs to turn into attitudes, values, in other words, feelings such as desired, good, valuable belonging to the individual are needed. People have thousands of emotions. There are only hundreds of attitudes and a few dozen values (Yüksel, 2006:100; Robles, 2019). Attitudes are the reasons behind people's individual and social behaviors. What attitudes have in common with beliefs is that they cause integration between behaviors and psychological processes. By expressing the attitude as the organization of certain beliefs about a particular object or situation, Rokeach stated a unity between beliefs and values. According to Güngör (1998: 29), when a person has a value, it is a principle that needs to be protected and creates the emotional basis of showing a specific behavior and directs people to behave in a certain way. Looking at these characteristics, it can be argued that there are commonalities between values and attitudes.

Whether the values are private, business, social or economic, their characteristics ensure that life continues within the framework of certain norms. While norms are rules of behavior, values are principles, criteria, and standards that guide human attitudes and behavior. Therefore, there is a close semantic relationship between these two concepts. When values are started to be lived, they become norms and become a rule-making principle for life. Values are the basis of every norm. These can be either religious values, moral values, or another value system. Every norm can be based on various values (Schwardz and Bilsky, 1987: 551). For example, not taking a bribe for a public servant is both a rule and a reinforced behavior with various values such as rights, law, and morality. The main difference between value and norm is that value is more general and abstract than norm, including norms. While values are the basic principle, norms are special rules that determine the application of this fundamental principle in particular situations. While norms mostly show the rules that people with specific roles must follow, values cannot be mentioned about certain people and generally 
include everyone. While norms are usually written down, values are generally unwritten and occur in society's collective memory.

In order to clarify the definition and characteristics of values, Schwartz and Bilsky determined the characteristics of the agreed values as follows (Kuşdil and Kağıtçıbaşı, 2000: 60; Ulu, 2018: 190):

Values are beliefs. However, values are not objective and emotionless like beliefs. When they gain functionality, they are intertwined with emotions.

Values indicate goals and objectives. Values are related to the individual's normative goals (such as equality) and the behavioral patterns (such as fairness, benevolence) that effectively achieve these goals.

Values are not specific actions and facts. Those with a particular system of values show them in all areas of life, not in a particular area. For example, the value of "obedience" or "loyalty" regulates one's private life and work and family life.

Values are standards. Values and beliefs are intertwined. Values serve as standard criteria in a behavior or a preference.

Values have priorities. Values are ranked among themselves according to their importance. An ordered set of values creates a system that prioritizes values.

\section{B. Formation and Classification of Values.}

While a person lives in a particular society, he begins to assume its values over time. In some cases, it brings its values to the society in which it lives. Hz. As Muhammad said, "If you do not live as you believe, you begin to believe as you live." Values that affect people's lifestyles are realized by learning social roles in society. Values are initially acquired through stimulus coupling, also known as classical conditioning. Social values are acquired through operant conditioning. In any society, theft is not honored as a value. There is no society in which torture, terror, injustice, and oppression are glorified as values. All such behavior is met with punishment or reprimand, in short, a sanction.

According to Rokeach (1973: 3), values shape according to belief systems and are influenced by culture, society, institutions, and personality. At the same time, values are an integral part of a person and manifest themselves in every aspect of his life. Values are learned through social roles and transferred to the next generations. Social roles include factors that form an identity, such as occupational, social, and personal. Values have an 
important place in the formation of identity structures shaped by social roles. Values indicate what is right and what is wrong while performing various social roles. For example, while courage, perseverance, perseverance, and composure are seen as masculine values for a man in the formation of gender identity; For girls, feminine traits such as protectiveness, compassion, and sensuality are seen as values. Thus, values are formed and maintained through social supports and reinforcers (Wiener, 1988: 545; Martinez, 2017). When viewed in the context of Akhism values, it aims to create a social solidarity culture. It forms the abstract element of ahi-order life by combining and feeding each other with Turkish culture and Islamic beliefs. Akhism value patterns have been transferred to the next generations through acculturation by the ahis and have reached the present day.

As for the classification of values, a binary distinction is usually made. Values can be handled under two headings: individual values and business values. However, when the lower distinctions are made, values can generally be mentioned as three fundamental values: aesthetic, moral, and economic. Aesthetic values include the value of cultural products and actions. Aesthetic value is the objects and activities prepared for art and especially cultural products consumed by the ruling classes in society. Aesthetic value can be linked to economic value. The primary purpose of aesthetics is not to attribute deceptive beauty to objects but to add a microscopic level of economic value (Edgar, 2020). On the other hand, economic value concentrates on the value attributed to commodities (Goodstein, 1983: 203; Foret and Calligaro, 2018). Marxism is notable for its appeal to the labor theory of value, in which the exchange value of a commodity depends on the amount of working time spent on its production. In contrast, orthodox economics explains value through reference to the interaction of supply and demand in the market.

What we are focusing on here are business values, and business values are values related to "the nature of work" and "the results of work," "real," and "secondary." Primary or absolute values related to the nature of work include choices such as adopting a challenging or exciting job, acquiring new knowledge and skills at work, revealing full potential, taking responsibility and independence, and being creative. On the other hand, secondary values related to the work results, on the other hand, express preferences such as providing economic and social benefits such as money, status, trust, or allowing time for family and hobbies (Timuçin, 1994: 60). 


\section{The Function and Regulatory Quality of Values}

Values shed light on the stance and behavior of the individual in the face of social events. A person's values have an impact on his attitude and behavior. Values also help the individual act according to social norms by forming the source of norms (Umanailo et al., 2020; Gouveia, 2019). Values also help people know themselves and others, as there are values behind every attitude and behavior. One of the essential functions of values is to act as a harmonizer by ensuring that the individual behaves according to behavior and social norms.

Values and moral principles provide reliable guidelines or standards for regulating interpersonal behavior. Standards are principles that regulate behavior and evaluate good or bad (Hofstede and Luk, 1993). Values are sometimes perceived in different ways, such as preferences among lifestyles, sometimes basic assumptions about the place of human beings in the world, and sometimes the target of any need, attitude, or desire (Rindova, and Martins, 2018). Values provide an essential criterion for choosing between alternatives suitable for distinguishing between "good" and "bad" and judging attitudes and behaviors. It creates the attitude and behavior criteria of people's individual and business lives. In this respect, values are not only the source of behavior but also its criteria. The practical value in forming a particular behavior also determines how it is and sets out the standards, beliefs, or moral principles accepted by the person or social group. Values, in a way, form the criteria of lifelong commitments, attitudes, and behaviors. Values also have an important place in the perception of the self (Güngör, 1998: 27). People perceive themselves within the framework of their value systems and define themselves according to their values. In this respect, the value indicates whether something is desirable or undesirable.

Values function as beliefs and norms regulating work and social life as criteria that guide people's attitudes and behaviors. Values, above all, function as control elements when applied to people's attitudes and behaviors. The most crucial function of values is to be the standard or criterion that guides behavior in various situations (Robbins, 1992: 25; Rindova and Martins, 2018). It is not easy to understand and explain a person's behavior without knowing the values that guide his thoughts. People behave according to the values they adopt. Therefore, values also function as criteria for knowing the individual. An individual's values are essential in understanding and explaining his/her behavior (Tetenbaum, 1998). In terms of its functional aspect, values have a directing effect on 
human behavior. This aspect of values is related to people's preferences. Interest in something is an indication of whether the individual likes or dislikes the thing in question. Therefore, if something becomes an "interest" or "attitude object" for an individual, it means it has "value" for him. A person who believes in any value feels the need to act under the regulatory power of that value.

One of the essential functions of values is that they are motivational tools. One factor that guides people's goals and objectives is to be hardworking, productive, and valuable to society, showing the motivating function of values in reaching one's goals and objectives (Korchagin et al., 2018). Values are used as criteria in judging attitudes and behaviors. It gives an identity and personality to people who act from values rather than conjuncture in their behavior. In this respect, values contribute to selfactualization by enabling people to act according to normative principles. In this sense, values guide and guide the selection and evaluation of behavior patterns.

Values form the distinction between good- because they are the criteria that people adopt in evaluating and judging their situations and actions (Sağnak, 2005: 209; Bauer, 2017). Value definitions with different approaches show that value has properties such as a belief, a psychological state, an explanation and evaluation tool, and guiding people's behaviors. Values have functions such as making moral judgments and making sense of social behaviors. Values determine individual and social perceptions, the interpretation of interpersonal relations, and the attitude to be taken in the face of events and facts.

\section{Global Compact Values System}

The ethical code and social values, which differ from society to society according to the beliefs and values on which they are based, are generally based on the principles of equity and human rights. Here, the principle of fairness means that everything should be as it should be and take place following the principles of justice. The principle of human rights, on the other hand, means the protection of individuals' right to life, enterprise, belief, thought, and action. This is true for the Global Compact, and the ahi-order values created about a thousand years ago (Thompson and Milter, 2018; Lentner and Parragh, 2017). The United Nations Global Compact is the largest corporate sustainability initiative in the world. The platform, which was established in 2000 with the initiative of the United Nations Organization, has 10 Principles. These principles are based on four United 
Nations declarations on "human rights", "labor standards", "environment" and "anti-corruption". These declarations; Universal Declaration of Human Rights, the International Labor Organization (ILO) Declaration of Fundamental Principles and Rights at Work, the United Nations Rio Declaration on Environment and Development, United Nations Convention Against Corruption. Ahi-order values that emerged about a thousand years ago take their source from the Qur'an, Sunnah, and Turkish culture. In this research, the value systems created by two different beliefs and cultures will be compared by content analysis.

The 10 Principles of the United Nations (U.N.) Global Compact address the core responsibilities of business in human rights, labor standards, the environment, and anti-corruption. It aims to incorporate the ten principles of the business world into its strategies, policies, and procedures. It aims at working standards and protecting the environment. The 10 Principles of the United Nations Global Compact are universally accepted. It continues its activities in more than 70 countries on a local scale to make the United Nations Global Compact principles dominate business life. Global Compact Turkey (www.unglobalcompact.org), the Turkey Local Network of the United Nations Global Compact, keeps these values alive and disseminated through a multi-participant structure that includes non-governmental organizations, universities, and municipalities, well as companies that take responsibility for sustainable development.

While the Global Compact supports the development of its members in sustainability, just like the principles of Akhism, it seeks to share good practices both locally and globally. The principles of the Global Compact are carried out by a platform established in Turkey in 2013 by the partnership of TÜSİAD and TISKK, and TÜSİAD carries out its secretariat. Global compact Turkey has determined its vision "to be a pioneer and an example globally with the strategies and approaches it has developed to ensure that the concept of "responsible corporate citizenship and sustainable institutions" becomes widespread in Turkey. The institution's mission is determined "to support the provision of a sustainable and inclusive global economy by collaborating with the private sector and other social stakeholders in Turkey and internationally" (www.globalcompactturkiye.org).

In order to realize the vision and mission of Global Compact, it has determined a set of values under four headings: Global Compact Human Rights Values, Global Compact Labor Standards, Global Compact Environmental Values, Global Compact Anti-Corruption Values. These values 
defined by the Global compact cover the essential duties and responsibilities determined below (www.unglobalcompact.org).

\section{Global Compact Human Rights Values}

Principle 1: Businesses should support, and respect proclaimed human rights: Businesses should not cause or contribute to opening human rights through their activities. The business must be responsible for the negative consequences of its activities. It should voluntarily support human rights. For this purpose, businesses should support investment and philanthropic activities and respect human rights in all their activities.

Principle 2: Businesses should not be complicit in human rights abuses. Businesses should make it a principle not to be involved in human rights violations by the government or individuals.

\section{Global Compact Working Values}

Principle 3: Business should support workers' freedom of association and collective bargaining: Freedom of association refers to the right of all workers and workers to freely and voluntarily form and join organizations of their choosing. These organizations have the right to carry out their activities freely without interference, including supporting and defending their professional interests.

Principle 4: Forced and compulsory labor should be stopped. Employing forced and compulsory labor; slavery, bonded labor or debt bondage, detention and kidnapping, confinement to the workplace, labor, and services of prisoners cannot be forced to work overtime. Applications such as withholding documents required for the job, leasing, non-payment of wages, and incentivized borrowing cannot be made.

Principle 5: All forms of child labor should be stopped. Child Labor is a form of exploitation that is a violation of human rights. While the term 'child' refers to all boys and girls under 18 , this does not mean that everyone under 18 should suspend from work.

Principle 6: Eliminate discrimination in recruitment and placement: Discrimination in employment and employment, not related to merit or intrinsic needs of the job, race, color, gender, religion, political opinion, national and social origin, age, disability, HIV/AIDS It is the exposure of people to different or negative behaviors due to characteristics such as status, union membership, and sexual orientation.

\section{Global Compact Environmental Values}

Principle 7: Businesses should support precautionary approaches to 
environmental problems. Where there is a threat of severe and irreversible damage, it cannot be used as an excuse to delay taking economic measures to prevent environmental degradation. Businesses should support economic measures to protect the environment.

Principle 8: It should support all kinds of activities and formations that will increase environmental responsibility. Business and the private sector should increase self-regulation, guided by appropriate laws, regulations, and initiatives integrated into business planning and decision-making; promote transparency and dialogue with employees and the public.

Principle 9: Support the development and dissemination of environmentally friendly technologies. Environmentally friendly technologies; It encompasses technologies that protect the environment, reduce pollution, use all resources more sustainably, recycle more waste and products, and manage waste more effectively than can be used instead.

\section{Global Compact Anti-Corruption Values}

Principle 10. United Nations Global Compact participants avoid bribery, extortion, and other forms of corruption and develop policies and concrete programs against corruption. Corruption is a considerable obstacle to economic and social development around the world. It has negative impacts on sustainable development and mainly affects poor communities. For companies, corruption involves significant risks, first of all. It hinders business growth, destroys trust, damages firm reputation, increases costs, and creates legal risks. Corruption also increases transaction costs, prevents fair competition among companies, and hinders long-term foreign and domestic investments due to trust problems. It creates financial, operational, and reputational risks for investors. Therefore, stricter measures should be taken worldwide in the fight against corruption. Companies have to take anticorruption measures to protect their reputation and the interests of their stakeholders.

\section{E. Ahi-Order Values as a Total Values System.}

Akhism is a form of non-formal education institution and business organization that emerged during the Seljuk period and was especially effective during the rise of the Ottoman state (Akyüz, 2001: 48; AydoĞan and Delibaş, 2017). Although the establishment the Akhism is shown as the Seljuk period, the origin of the Ahi organization is based on the Futuwwa Organization (Şahin, 2006: 299), which was known Islamic society since the second century the Hegira and was established union futuwwa (TurkishIslamic guild) tradition unions (Şahin, 2006: 299). In this respect, the Ahilik 
Organization, XIII. It is possible to say that it has foundations dating back to Iranian geography earlier than the century (Ocak, 1996: 129). Although the Ahi community may seem like an artisan organization at first glance, when it is evaluated in terms of its purpose and objectives, it is understood that it is a structure that regulates the relations between all individuals and institutions of the society. It can be said that the aim of Ahi Evran, the founder of Akhism, was to equip people with religious and professional knowledge and skills, to achieve happiness in the world and the hereafter, and to reach the level of a perfect human being (Kllavuz, 2005: 616; Köken and Büken 2018). The values of the Ahi community are a system of values and norms that encompass all areas of life, including economic, cultural, social, political, and religious aspects of the individual and society.

Akhism; is a way of life based on friendship, brotherhood, bravery, heroism, independence and free life, production, hard work, and honest work in the social order. It is a creative, constructive, cohesive Turkish conception of the universe (Karaman, 2014). It emerged as a requirement of the understanding of futuwwa, which means hospitality, generosity, and bravery, which emerged in the first centuries of Islam. Social, economic, political-political, educational, and cultural values are the values that are wanted to be kept alive and glorified in Akhism. The primary purpose of these values is to create social capital to construct a strong civilization (Akgül, 2017). For this, first of all, human and human values are acted upon. It is essential to ensure that people have a profession for the social capital to construct social values. We act with the awareness that it will not be easy to build a civilization from people who are not economically self-sufficient.

For this reason, ahi-order is not only a vocational training institution but an understanding that aims to ensure that its followers lead a valuebased life. Akhism is both a formal organization and a system of organized and institutionalized values. Its primary purpose is to defend its members' rights, enable them to practice their craft competently, and function as a control mechanism.

Ahi-order is both a vocational non-formal education institution and a mentality that tries to establish the morality of futuwwa (Durak and Yücel, 2010: 151). Even though it is similar to the chambers of tradespeople in today's sense, it is a structure that protects the rights and interests of the tradesmen and an education and knowledge institution. In the Ahi system, all tradesmen and artisans were gathered under a single organization and gained moral and professional competence (Arslan, 2015). The focus of 
Akhism is tradesmen and raising human resources suitable for the civilization it aims to build. The education in Akhism is not only business and vocational education but also moral and military. However, moral education in Akhism is higher and more dominant (Erken, 2008). With the awareness that the fundamental values that sustain social life are morality and a sense of justice, the Ahi community acts that it is impossible to maintain a belief system and social structure deprived of morality and justice (Sancakl, 2010). The fundamental values taught by the Ahi community are to behave pretty in market relations, to be honest, reliable, and measured in purchases and sales, to be virtuous and dignified in social relations. They are universal values that are still accepted today, such as not deceiving and inspiring confidence.

Being aware of the need for an educated society to construct and maintain social values, the Ahilik attaches particular importance to education. The primary purpose of education in Akhism values is to be human first and ensure that people become perfect human beings (Durak \& Yücel, 2010). It starts with the individual and tries to make him a person with high self-esteem and character. For this, the main aim is to prepare the individual for life from childhood. For this purpose, they are encouraged to be measured, balanced, moderate, just, generous, and brave from childhood. Children's education is inculcated to respect people and all living things on earth and observe their rights. They are advised to be afraid of the servant's rights and not have anything worth their effort (Esmer, 2020). They are required to stay away from anything that weakens their will and follow Allah's orders and prohibitions meticulously for them to happen and have a job to be self-sufficient.

The basic principles of Akhism are knowledge, deeds, patience, gratitude to Allah, and sincerity. Here, the deed covers all kinds of religious and worldly activities. Religion cannot be thought of as separate from the world and the world from religion. The basic features required to be found in Akhil are shown in three basic moral principles in futuwwa names. According to the expressions in the Fütüvvet names; Three things of an ahî should be open, and three should be closed. Ahî's hand (generous), door (hospitable), and table are open; eyes, waist, and tongue should be closed. (Çakmak, 2005; Aksay, 2020) Ahi is the man who puts a watcher over the conscience itself. Akhism is open to anyone who accepts the principles stated in the futuwwa names. It is aimed to bring these values to both the individual and the society.

The basic principles of Akhism are related to the professional and 
moral upbringing and maturation of the individual. At the same time, these principles are aimed at the zoning and construction of the social order. Human rights, working values, environment, and anti-corruption will be used as the central theme of the Global Compact in order to see and compare Ahi values and global compact values more easily. Accordingly, it is possible to group the principles of ahi-order within the framework of global Compact as follows (Aras, 2012; Aydın, 2011; Durak and Yücel, 2010; Göktaş, 2011; Aksay, (2020):

\section{Akhism Human Rights Values}

Human comes first at the beginning of the value system of Akhism. This is where the motto "Let the people live so that the state can live" originates. For this, it is aimed to be a person who has chastity, generosity, and virtue. Giving without expecting anything in return and without a purpose is an essential human rights value. Another significant ahi value that can be examined under this theme is to be on the middle ground between anger and cowardice, that is, to act following the principle of bravery. Avoiding arrogance, envy, hatred, and anger is an ahi-order value (Gölpınarlı, 1949-1950). Another essential value taught in Akhism is wisdom. This value is one of the most frequently emphasized principles in futuwwa names. Wisdom is to be in moderation. Wisdom is to understand the facts as they are, to act correctly in matters. Habits such as seeing oneself as superior, putting oneself to the forefront, being lax, and boasting are condemned as traits against human rights (Altıntaş and Doğan, 2003: 81). For this reason, it is an essential human right principle to avoid all kinds of bad words and insults.

Keeping secrets, being generous, and doing good are essential ahiorder human rights values. Staying away from selfishness and hypocrisy is necessary, especially for individual development, virtue, and virtue. In addition, it is especially emphasized to maintain relations with friends and relatives, not to deal with their kindness (Aksay, 2020). It is among the human rights values of Akhism not to expect anything in return for his good deeds, not to make mistakes, attach importance to friendship, be forgiving, and respond to those who do evil with kindness. Being respectful to the elders, forgiving, compassionate towards the weak, being soft-spoken, sitting with virtuous people, being good-natured, and having good morals are among the human rights values of Akhism. Other human rights values of Akhism are not to brag about the world's possibilities, not to be arrogant, to know one's word and to keep one's word, to have a sense of shame and 
resentment, to command good forbid evil. To keep secrets, to go to those who do not come, to visit friends and relatives, to be one with one's inner, outer, essence and word, to keep one's hands, table and doors open, to keep one's tongue, eyes and waist tied, to control oneself, to obey Allah's orders, to avoid His prohibitions being kind and hospitable, not telling lies, avoiding slander and gossip, being just, resisting oppression, cruelty and injustice include the principles of Akhism regarding human rights (Kılavuz, 2005; Pala, 2007). The primary motto of Turkish societies, love for the little ones and respect for the elders, and respecting people not because of their status but because they are human, are the fundamental values of Akhism.

\section{Akhism Working Values}

In Akhism, it is recommended that every individual in society have an art and a profession. Working to reach the morality that Allah is pleased with is an essential ahi-order value. Being correct and reliable in one's work, loyal to one's promise word, and love are essential Akhism values. Mastering a specific art and profession, or even specializing in today's sense, is the basic principle of ahi-order business ethics. Learning a profession from those who know the best, having a job done by the best person, and consulting him is due to the importance given to professional management and business ethics by the Ahi community. It should be determined that following the sublime motto "give the relics to their owners" shares this (İhsan, 2017). It is desired to keep people alive as a principle to do their best to get rid of ignorance, specialize in specific fields, and transform skills and abilities into non-formal education in today's sense by teaching those who know to those who do not. Being friendly towards people, patient, controlling one's anger, being humble, and faithful to one's word while doing their job are essential business and professional ethics principles. In addition, it is an essential moral code to show the critical importance to his work and do business in a certain quality standard according to business and professional standards such as "putting the shoe on the roof." Desiring everyone to work, finding a job for the unemployed, making everyone a profession, helping the needy are among the values that Akhism is sensitive to.

In Akhism, sharing more than what is needed with other people in need, not exploiting nature, resources, and other people, and operating by keeping a balance between human-nature goods constitute essential areas of social responsibility (Arslan, 2015). Akhism is a form of organization with a hierarchical structure. There is a hierarchy in the form of apprentice, journeyman, and master. It is an essential ahi-order value that people in 
different positions act loyally towards each other. Loyalty is one of the ahiorder values that must be possessed for the principle of justice. Fütüvvet is loyalty, he advises by saying, "Be loyal even to your ahi-comrade" (Gölpınarl,, 1953-1954; Akça, 2017). In addition, it is a crucial ahi value to give a sense of security so that the work is done as it should be. One of the essential working values to be focused on is the principle of justice. Justice is defined in futuwvet names as getting the right from everything and giving everything its due (Gölpınarl, 1949-1950). This value is of great importance, especially in terms of mutual protection of the rights of workers and employers. Not to betray other people's property and not to discriminate between people is an essential ahi-order value. Giving importance to the interests of everyone with whom he has a relationship of interest as much as his own, giving particular importance to being fair in his word and work are among the glorified values of Akhism. He is the one who earns from the halal Ahi, spends in his place and enough, is competent in measuring, produces valuable things, and helps (Akça, 2017). Akhis are people whose hearts are open to Allah, whose doors are open to seventy-two nations, who are on the path of prudence and mercy, who are based on generosity, who take morality as the principal capital and follow the path of reason, who seek knowledge, and who do not give up on doing practical work by acting on their knowledge. He is a person who reached the qualities of valor by the people of futuwwa and has also learned art.

\section{Environmental Values of the Ahi Community}

The Ahis, engaged in trade, have shown an essential educational activity in many social, cultural, and environmental fields. The value is given to human beings and other creatures in the ahi-order require that the Ahi approach their environment and nature with respect and care, and this requires that lessons and practices are included in the Ahi's upbringing. Therefore, Akhism may have an ethical dimension related to the environment and nature (Oğurlu, 2016). The primary purpose of Akhism is to raise people who can adapt to the environment, act in a balanced way in their behavior and respect the rights of the environment. The value given to humans and other creatures in the ahi-order and the respect and care given to the environment and nature by the Ahi stems from the belief and cultural values of the ahis (Erken, 2012: 76). They are giving the ahis a content character far from wastage results in the Ahi being environmentally friendly.

In addition to labor power, it is essential not to exploit natural resources but to ensure the welfare and peace of the individual and society 
by protecting the principles of justice and balance among them (Arslan, 2015: 253). In the Ahi organization, production was considered a need function, and production was adjusted according to need. This understanding shows that although the ahis affect their environment, they are in a harmonious balance with the environment (Bayram, 2001:10). The Ahis has established a social security mechanism that will protect the rights of society and nature and the workers and consumers. The Ottoman society is a patriarchal society based on customs and traditions, and particular importance is given to customs and traditions for the social structure to survive. It is suggested that the moral, moral and social environment of the Ahi community is a whole. Fear of Allah in Ahi-order prohibits people from all kinds of evil, including respect for the environment. Fear of Allah and the concern of gaining Allah's approval require respect towards one's social, cultural, physical, and economic environment.

\section{Anti-Corruption Values of Akhism}

In the context of fighting against corruption, in Akhism, there are principles such as protecting and taking care of people's entourage and servants, keeping their hands, tables, and doors open, keeping their tongue, eyes, and waist tied, and self-control. In this context, fundamental moral principles include obeying Allah's orders, avoiding his prohibitions, being just, and resisting oppression, cruelty, and injustice (Pala, 2007). Ahi, a connoisseur of futuwwa, is honest, that is, neither deceiver nor deceived. He stays away from lies and haram. Thanks to the organization they established among themselves, the Ahis aimed to fight against all kinds of corruption in the society with the self-control by using religious arguments and activating social sanctions. It is aimed to bring moral values to the addressee with social control or the conscientious convictions of the person (Şahin, 2007). Likewise, social control aims to prevent social degradation, theft, and corruption or establish a structure that will not allow them.

The social control provided by the norms and rules of Akhism cannot be realized with a simple system of orders and instructions. It should be accepted that education has an essential function in providing social control in Akhism (Tekin, 2006). Since the members of the Ahi community are accountable to a specific authority in this way, it is aimed at a controlled and principled human typology and a social structure that does not allow corruption (Yiğit, 2017). Religious, legal, social, and conscientious sanctions have always been used to gain moral virtues and avoid corruption. 


\section{F. Method}

\section{Research design}

In this research, the United Nations global compact and ahi-order values; The language used was compared in terms of thought and mental structure. The language used in a text does not consist of stray words or sentences. That is, nothing that is said is simply said. Words and sentences carry the traces of the belief system and culture to which they are attached. Language is the reflection of the mentality of the person who uses it with words. Language gains meaning with the structures, words, sentences, and paragraphs it creates. The element that provides this is the semantic connections of words and sentences that play an essential role in analyzing the text and discourse.

On the one hand, a text consists of the external structure that connects the external elements of the text, and on the other hand, an internal structure that reveals the meaning of the text. The analysis of the external structure of the text is done by text analysis, and the internal structure of the text is analyzed by discourse analysis. In other words, the analysis of the grammatical structures of the text is with text analysis; Revealing the implicit, implied and deep meaning hidden in the content of the text is through the analysis of its internal structure, namely discourse (Börekçi, 2008: 110). Briefly, text analysis is a technique used to reveal the superficial meaning of a text. Some visual elements are used to compare texts (Witte and Allen, 2000). In this way, the meaning hidden in the essence of the text is brought to light. Thus, by looking at which words the meaning is conveyed in the compared texts, the mind maps of the text creators are revealed (Ayata, 2005).

A text consists of letters, words, sentences, and paragraphs, meaning units of its symbols (Karaağaç, 2013). It is a language system produced orally or in writing by people in a specific communication context. In other words, it is a dynamic, action-oriented whole with a communication value. A written or spoken document without a communication function is not a text. In short, the text is a meaningful structure in which linguistic signs that form a closed structure with its beginning and end come together (Günay 2003: 35). Since the text's theme and the message the text wants to convey are hidden in the discourse, not in the words of the text, the discourse analysis technique is preferred in the research. In this way, only the textual meaning of the sentences was analyzed by text analysis, and the deep meaning of the sentences was analyzed by discourse analysis. In the research, the text is 
defined as a physical product and analyzed.

On the other hand, discourse analysis aims to reach the deep and implied meaning of the text and the superficial meaning of the text by trying to establish the reader's interaction with the text (Widdowson, 1973). Discourse analysis is to go beyond the sentences that make up the text to understand the author's purpose in the background of those sentences. The primary purpose of discourse analysis is to explain the reason for connecting sentences with elements such as time, space, and subject, depending on words and sentences and interpreting the text accordingly (Sözen, 2017: 31).

\section{Analysis of Data}

The research's main question problem and general-purpose, text analysis, and discourse analysis techniques were used together. Since the research deals with the superficial meaning of the text and the connotation, deep meaning, and implied meaning, the discourse analysis technique was also used in the research besides text analysis because ensuring the integrity of the meaning of the two texts being compared is related to the concept of discourse. In qualitative research, such as discourse analysis, text; format, theme, more frequently used word types can be analyzed in different ways such as author-centered, reader-centered, or text-centered. This research compared the global compact principles and the ahi-order values and subjected them to a text-centered solution. In the analysis of the texts, the ready themes of the Global Compact were used, and the Akhi community's values were subjected to discourse analysis on the themes in question. In the research, themes analyzed the discourse established in the text, the impression of the human mind, and its structure. In the analysis process in the research, meanings of the words and sentences are analyzed in line with the general-purpose research, not through letters and paragraphs. For this purpose, two different values are given with word clouds by visualizing the strings with word clouds. In the data analysis process, NVivo 12 qualitative data analysis program was used. Both texts were subjected to discourse analysis in terms of their meanings; the framework of the codes and main themes emerged later.

\section{Comparison in terms of the main theme of human rights values}

Working values of Global Compact, depending on the main theme of humans, are gathered around codes (concepts) such as rights, business, activity, and support. In addition, it is seen that the human rights values of Akhism are primarily gathered under the main theme of humans. The concepts or codes of Akhism consist of a system of pro-individual and social 

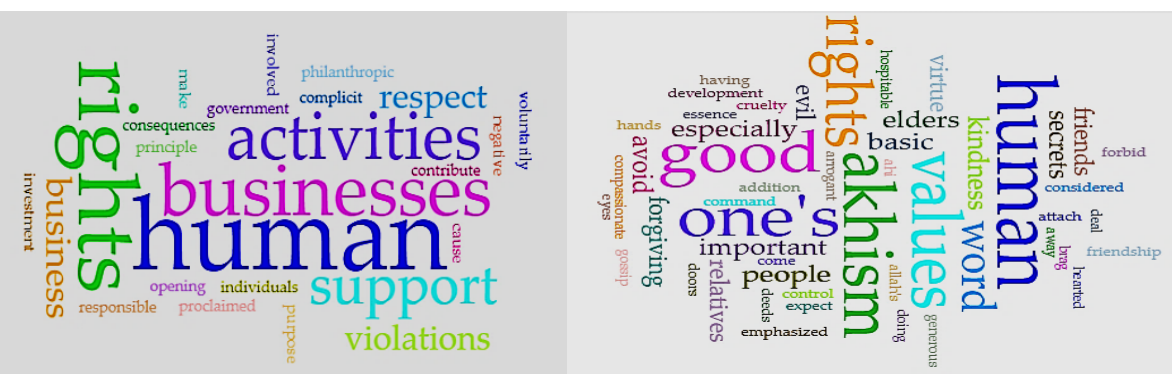

Figure. 1. Global Compact and Akhism human rights values (left side global compact, right side Akhism values).

values such as brotherhood, the world, rights, avoidance, values, the importance of the other. It is seen that the motto of Akhism, "let people live so that the state can live," is reflected in the word cloud. However, it is seen that Akhism expects people to show chastity, generosity, virtue, and hard work. When we look at the concept clouds, it is understood that while the global compact acts with more worldly and secular concerns, while the ahiorder is reconstructing this world, it is understood that it acts with an understanding that does not neglect the other world.

\section{Comparison in terms of the main theme of labor values}

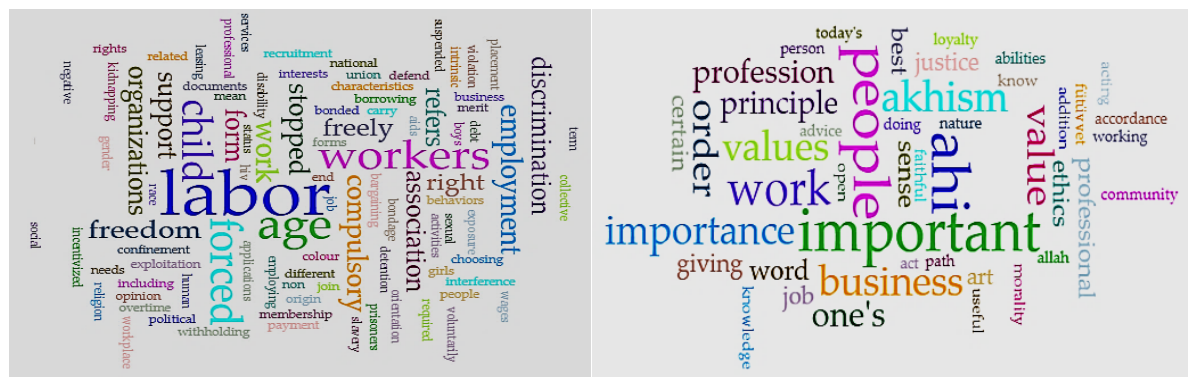

Figure. 2. Global Compact and Akhism labor values (left side global compact, right side Akhism values).

When looked at in terms of working values, global compact labor is gathered under the main theme. Working values of Global Compact; worker employment, child labor, freedom, organization, discrimination are gathered under the concepts and categories. The working values of Akhism are gathered under the main theme of the importance of human beings. In addition, the working values of Akhism differ with its attitude that considers this world and the next world simultaneously under its main theme. It is understood that the Ahi community glorifies humanity, brotherhood, professional development, order, and stability, living together with values, society, and being forgiving. The Global Compact differs from the secular 
principles and conventions regarding its working values, while Akhism's attitude constantly observes Allah's consent. Akhism is understood in addition to the fact that every individual in the social art and profession glorifies moral values to please society and Allah's consent. In addition, it is seen that working from the word cloud has an essential ahi-order value.

\section{Comparison in terms of the main theme of Environmental}

\section{Values}

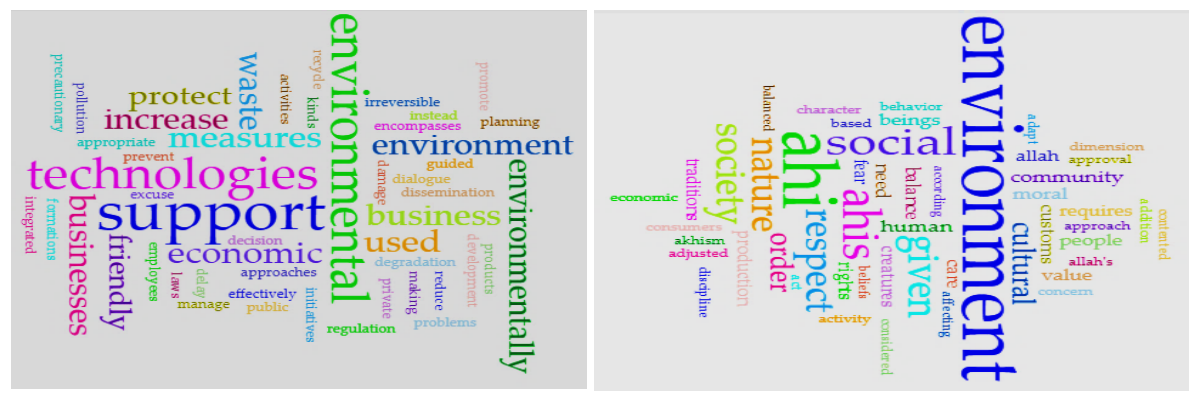

Figure. 3. Global compact and Akhism environmental values (left side global compact, right side Akhism values).

Looking at the word clouds in terms of environmental values, global Compact and Akhism have similar value strings. While Global Compact attaches importance to concepts such as the business world, the private sector, and business planning, it is seen that the concept of "social environment" is more emphasized in Akhism. In addition, it is seen that special attention is paid to the prevention of waste in the global compact value system. In Akhism, it is seen that particular importance is given to the concept of discipline, balance, social control, fraternity, making donations, considering the social and physical environment together, and respect for nature. It is understood that the value given to human beings and creatures in Akhism is reflected in the word cloud because the primary purpose of Akhism is to raise people who are compatible with the environment, balanced in their behavior, and know-how to respect the rights of the environment.

\section{Comparison in terms of the main theme of Anti-Corruption}

It is understood from the word clouds above that corruption, which is the main problem of significantly underdeveloped countries, has an important place in the value system of both global compact and Akhism. However, in the fight against corruption, while social control is given importance in Akhism, corruption is identified as a common problem in the global Compact. It is understood that the fight against corruption is gathered 


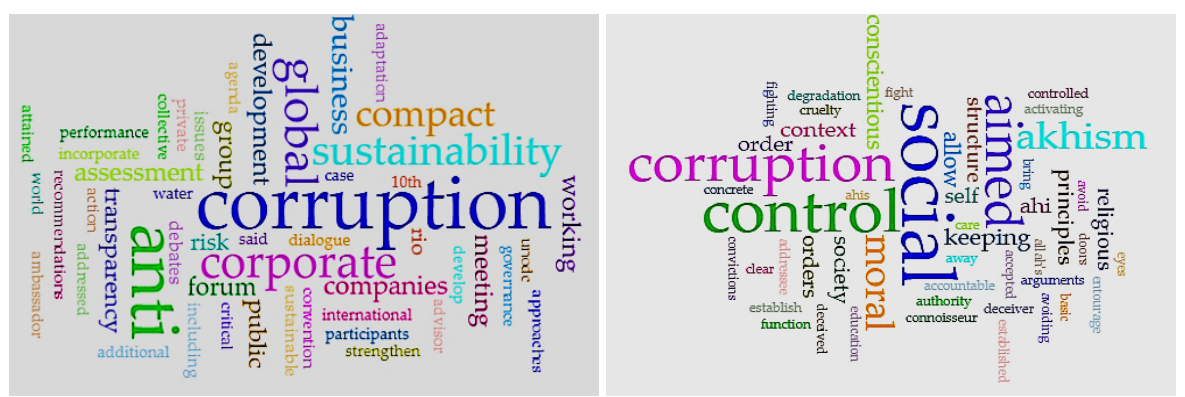

Figure. 4. Global Compact and Akhism anti-corruption values (left side global compact, right side Akhism values).

under the concepts of partnership, cooperation, world, development, contract, anti-corruption, and transparency in the global Compact. Global Compact wants its participants to live in principle only to avoid bribery and other forms of corruption. In Akhism, the fight against corruption has been considered in the context of more moral and religious values such as social control, the purpose of the ahi-order, social order, moral values, and religious rules. It is understood from the main themes and codes reflected in the word cloud of the mentioned values of the Akhism, which considers not to be a slave and to be fair above all human values. In the fight against corruption in Akhism, it is handled within the framework of the slogan of keeping your hands, your table, and your door open, and keep your tongue, eyes, and waist tie. Following Allah's orders, avoiding His prohibitions, being just, and resisting oppression, cruelty, and injustice are essential values of Akhism in the fight against corruption. In this context, it is requested that the ahî, a person of heart and mind, who has been brought up with the morality of futuwwa, should not be

\section{Discussion and Conclusion}

As a result, when we look at the above-mentioned ahi-order values, it is immediately apparent that these are the values that emerged with the ahiorder and the beliefs and values originating from Turkish culture and Islam (Oğurlu, 2016). The cultural codes of the Turkish nation have an essential place in addition to the principles of the Islamic belief regarding social life. It is possible to find these values in Ahmet Yesevî's Divanı-1 Hikmet and Hünkar Hacı Bektaş-ı Velî's Makalât, which is fed from the same belief and cultural roots. Adhering to these principles are important individual and social values against business and professional life polluted by capitalist mentalities, such as benefit, profit, profit, competition, stock, interest, and social life darkened by greed and dissatisfaction. 
In the historical process, it is seen that powerful states have strong social values and have strong social institutions. It should be considered an important policy to keep the ahi-order values, which left an indelible impact on Turkish history, on the agenda and to transfer them to future generations (Göktaş, 2011). There is a claim to be a model for the set of ahi-order values that have been tested and come of age many times to the world by preventing the moral erosion caused by popular culture in people. Transforming strong traditions into social values is essential in solving social problems (Altıntaş and Doğan, 2003Aksay, 2020). Akhism is an important social institution in terms of offering human and moral-oriented alternatives to solve social problems. It is essential to embrace the values of Akhism as a sacred heritage, which prioritizes service to humanity without discrimination and recognizes this as a human virtue by purifying it of all kinds of pragmatist thoughts.

Akhism offers essential opportunities in raising people who recognize national and spiritual values, adopt and respect these values, adapt to themselves, their families, society, and the environment, and work in cooperation (Arlan, 2015). Raising tolerant individuals who know how to share and strive to solve individual and social problems is the primary goal of states today as it was yesterday. In the social values system, business and social life values, which are sometimes drawn from the thoughts of Mevlana, sometimes Yunus, sometimes Hacı Bektaş-ı Velî and sometimes Ahi Evran, need to be adapted and kept alive with great confidence (Gölpınarlı, 19491950; Göktaş, 2011). Inherited as a historical heritage, Akhism can be the spiritual and material dynamics of building a civilization with high values. It is of great importance that the values that the United Nations organization is trying to keep alive today, such as Global Compact, are compared with the values of Akhism. This is also of great importance in terms of filling the gap in the literature.

Ahi-order values still contain the principles and behavioral norms needed by the individual and society today. It claims to be a solid alternative to the moral principles of bubbling consumption frenzy and brutal capitalism. The idea of producing to sell at any cost distracts people from both altruism and consumption morality. An understanding that thinks the satisfaction of the ego and being happy are the same erodes social values (Durak and Yücel, 2010; İhsan, 2017). The basis of many of the moral and social problems that societies experience is greed, insatiability, and selfindulgence. Dominating the hands, waist, and tongue of the Ahi community; |180| A person whose hand, table, and door are open and closed to his desires is a prototype for today as well. There is a great need for this type of person to 
prevent the harms of egocentrism to society and ensure social peace (Oğurlu, 2016; Yiğit, 2017). In an environment where everyone is striving to earn more money, spreading, establishing, and applying an extraordinary human and Islamic value such as thinking of others before themselves is an essential value of Akhism. What we have to do today is to update the values that the ahis have successfully applied in their time and to discuss how these principles can be applied today. It is thought that this research will contribute to this. These values are needed as much as yesterday to be among today's significant problems, such as living together, solidarity, self-control, chastity, wisdom, and justice.

Is the idea of ahi-order viable today? A question comes to mind. If living without earning, unnecessary consumption, waste, making money with money, the worthlessness of labor, and disposable culture is a social problem, then ahi-order is a solution (Brenner: 1999; Arslan, 2015). If unconscious consumption, the problem of not raising qualified people, lack of communication, artificial and superficial relationships, and production of poor quality goods are a problem, then Akhism is a solution to all kinds of poor quality (Oğurlu, 2016; Yiğit, 2017). If problems such as unending needs, passions, desires, inability to be self-sufficient, lack of thinking about others are critical social problems, the ahi-order values based on self-sacrifice and the principle of preferring someone else's self to oneself are the solutions themselves. An essential solution is to understand the Ahi community that gives its followers a moral structure, a solid character, a balanced life, and measured behaviors. If the greed of this capitalist person, whose sole aim is to earn more, is a problem in terms of the destruction of people and the environment, then it is an ahi-order solution that considers brotherhood, fraternity, solidarity, giving without taking, and being content as moral principles.

$$
\text { 䊏淡 }
$$

Acknowledgements:

\section{Declarations:}

1. Ethics approval:

Not applicable. 
Hasan TUTAR

The author declares no one has contributed to the article.

\section{Competing interests:}

The author declares no competing interests.

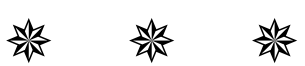

\section{KAYNAKÇA}

Akarsu, B. (1998). Felsefe terimleri sözlüğü. İnkılap Kitabevi., İstanbul, s.74

Akça, G. (2017). Fütüvvetçilikte Ve Türk Fütüvvetçiliğinde (Ahilik) İdeal İnsan Ve Ahlâkı. Electronic Turkish Studies, 12(3).

Akgül, D. (2017). Ahilik Kültüründeki Etik İlkelerin Günümüz İşletmelerine Yansımaları: Kırşehir İli Örneği. Ahi Evran Üniversitesi Iktisadi ve İdari Bilimler Fakültesi Dergisi, 1(1), 8-26.

Aksay, B. Authenticity, and Counterfeiting: A Qualitative Study in Babadağlllar Textile Bazaar, Turkey. Turkish Studies, 15, 4.

Akyüz, Y. (2001). Türk eğitim tarihi. İstanbul: Alfa Yayınları.

Altıntaş, A. \& Doğan, H. (2003). Osmanlı esnaf tabibinin ahlâk eğitimi ve değerleri (Fütüvvetnamelere göre). Türk Dünyası Araștırmaları, 146, 59-83.

Arslan, H. (2015) Ahîlik Teşkilatı'nın Sosyo -İktisadî Yapısı Ve Örneklik Değeri, Akademik Bakış Dergisi, Sayı: 49 ( Mayıs - Haziran 2015)

Ayata, Ş. C. (2005). Dilbilim: Metindilbilim ve Türkçe. İstanbul: Multilingual Yayınları.

Aydın, M. (1991), Kant ve çağdaş ingiliz felsefesinde Tanrı-ahlak iliş̧kisi, TDV Yay., Ankara, s. 52.

Aydın, N. (2011). Hz. Peygamber'in sünnetinde ahîlik değerler sisteminin temel referansları (ed.) Çavuşoğlu, A. Kayseri: Ahî Uluslararası Sempozyumu Kalite Merkezli Bir Yaşam Bildiri Kitabı.

Aydın, P. (2003). Eğitim ve öğretimde etik. Ankara: Pegem Yayıncılık. S.15

Aydogan, E., \& Delibaş, M. B. (2017). Ahılık Kurumu Ve Örgütsel Vatandaslık Davranısı/Akhısm Organızatıon And Organızatıonal Citızenshıp Behavior. Third Sector Social Economic Review, 52(1), 1.

Bauer, C. A., \& Bolsinger, H. J. (2017). The Value of Constitutional Values: An Exploratory Study of the Constitutions of India and Bavaria. Tattva Journal of Philosophy, 9(1), 13-30.

Bayram, M. (2001). Türkiye Selçukluları Döneminde Bilimsel Ortam ve Ahiliğin Doğuşuna Etkisi. Türkiyat Araştırmaları Dergisi, 10, İstanbul. 
Beck, J., Neupane, B., \& Carroll, J. M. (2018). Managing Conflict in Online Debate Communities: Foregrounding Moderators' Beliefs and Values on Kialo.

Börekçi, M. (2008). Atatürk'ün Nutuk'unda Söz Dizimi ve Üslûp Özellikleri. Uluslararası Sosyal Araştırmalar Dergisi. S. 1/5, s. 105-125.

Brenner, R., (1999). "Dünya Kapitalizminin Yaklaşan Krizi: Neo-liberalizmden Buhrana mı" (Çeviri: Pınar Bedirhanoğlu). Birikim (119) Mart 1999: 88-95.

Bussing, A. G., Menzel, S., Schnieders, M., Beckmann, V., \& Basten, M. (2019). Values and beliefs as predictors of pre-service teachers' enjoyment of teaching in inclusive settings. Journal of Research in Special Educational Needs, 19, 8-23.

Cevizci, A., (2000), Felsefe sözlügü, Paradigma Yayınları, İstanbul.

Çakmak, M. (2005). Ahîliğin dinî-tasavvufi temelleri. I. Ahî Evran-ı Veli ve Ahîlik Araştırmaları Sempozyumu 1 içinde (ss.249-260). Kırşehir: Gazi Üniversitesi Ahilik Kültürünü Araştırma Merkezi Yayınları.

Kagıtçıbası, Ç., (1980) Çocugun degeri, Bogaziçi Üniversitesi İdari Bilimler Yayınları, İstanbul, 21.

Durak, İ. \& Yucel, A. (2010). Ahiliğin sosyo-ekonomik etkileri ve günümüze yansımaları. Süleyman Demirel Üniversitesi İBF Dergisi, 15(2) 151168.

Edgar, A. (2020). Professionalization and aesthetic values. In Values in professional practice: lessons for health, social care and other professionals (pp. 35-45). Routledge.

Erken, V. (2008). Bir sivil örgütlenme modeli ahîlik. Ankara: Berikan Yayınları.

Esmer, Y. (2020). Etik Girişimcilik. Kastamonu Üniversitesi İktisadi ve İdari Bilimler Fakültesi Dergisi, 22(1), 35-55.

Fischer, E., \& Hänze, M. (2020). How do university teachers' values and beliefs affect their teaching?. Educational Psychology, 40(3), 296-317.

Goodstein, L.D. (1983). Managers, Values, and Organization Development.' Group and Organization Studies Vol: 8(2): 203

Gouveia, V. V. (2019). Human values: Contributions from a functional perspective. In Psychology in Brazil (pp. 67-81). Springer, Cham.

Göktaş, V. (2011). Ahîlik ve tasavvuftaki bazı müşterek ahlâki öğeler. Ahîlik Uluslararası Sempozyumu. Kalite Merkezli Bir Yaşam, ss. 107-124. 
Gölpınarlı, A. (1949-1950). İslâm ve Türk illerinde fütüvvet teşkilâtı ve kaynakları, I.Ü. İktisat Fakültesi Mecmuası, 11(1-4).

Günay, V. D. (2003) Metin Bilgisi, İstanbul: Multılıngual Yayınları

Güngör, E. (1998). Değerler Psikolojisi Üzerine Araștırmalar, İstanbul: Ötüken Yayınlarl., s.27

Tanrıverdi, H., Immanuel Kant'ın İman Anlayışı, Gümüşhane Üniversitesi İlahiyat Fakültesi Dergisi, 2012/2, c. 1, sayı: 2, s.191

Hofstede, G. \& Luk, C., (1993), İndividual Perceptions of Organizational Cultures; A Methodogical Treatase on Levels of Analaysis, Organizational Studies, Vol: 14, No: 4, 1993, ss. 483-503

Ismail, S., and Omar, Z. (2017). Academic dishonesty: An empirical study of personal beliefs and values of undergraduate students in Malaysia. Pertanika Journal Social Sciences \& Humanities, 25(3), 11811198.

Ihsan, C. O. R. A. (2017). Örgütlerin yönetimi açısından Ahilik örgütüne genel bir bakış; tarihi bir araştırma. Karadeniz Sosyal Bilimler Dergisi, 9(16), 251-279.

Joy, P., Crawford, Z., Sinno, J., Walters, J., \& Numer, M. (2021). A poststructural discourse analysis of the attitudes, beliefs, and values of undergraduate Canadian university students regarding sexual orientation. The Canadian Journal of Human Sexuality, (aop), e20200053.

Karaağaç, G. (2013). Dil Bilimleri Terimleri Sözlüğü. Ankara: Türk Dil Kurumu Yayınları.

Karaman, R. (2014). Türk ahi teşkilatının işleyişi ve çorum tarihinde ahilik. Hitit Üniversitesi Sosyal Bilimler Enstitüsü Dergisi, 7(1), 93-109.

Kılavuz, M. A. (2005). Ahîlik kurumunda din ve ahlâk eğitimi anlayışı. I. Ahî Evran-ı Veli ve Ahîlik Araştırmaları Sempozyumu içinde (ss. 615-628). Kırşehir: Gazi Üniversitesi Ahilik Kültürünü Araştırma Merkezi Yayınları.

Kılıc, O. H. T., Anıl, M., Göksu, M. G., Varol, U., Guvendı, G., Haytabey, B., ... \& Mete, B. D. (2021). Medical Faculty Students' Attitudes, Behaviors, and Beliefs About Covid-19 Pandemic. Izmir Dr Behcet Uz Cocuk Hastanesi Dergisi, 57-65.

Korchagin, V., Pogodaev, A., Kliavin, V., \& Zelikov, V. (2018). Implementing road safety measures in conditions limited by budget. Transportation research procedia, 36, 308-314. 
Köken, A. H., \& Büken, N. Ö. (2018). Ahi Evran (1171-1261) ve Ahilik ile Hekimlik Ahlakı Üzerine Bir Değerlendirme. Mersin Üniversitesi Tıp Fakültesi Lokman Hekim Tıp Tarihi ve Folklorik Tıp Dergisi, 8(1), 54-70.

Kuşdil, E. M., \& Kağıtçıbaşı, Ç. (2000). "Türk Öğretmenlerin Değer Yönelimleri ve Schwartz Değer Kuramı". Türk Psikoloji Dergisi, 15(45), 60

Lentner, C., \& Parragh, B. (2017). Interest Representation, Interest Alignment and the Role of Seeking Consensus in the Renewal Process of Hungarian State Management. Int'l Pub. Admin. Rev., 15, 71.

Maaranen, K., Kynäslahti, H., Byman, R., Jyrhämä, R., \& Sintonen, S. (2019). Teacher education matters: Finnish teacher educators' concerns, beliefs, and values. European Journal of Teacher Education, 42(2), 211227.

Martinez, D. M. (2017). From Construction of Knowledge to Emergence of Values: An example of community social pediatrics. Book Reviews, 9(3).

Mccarty, J.A., \& Shrum, L. J. (1994). The Recycling Of Solid Wastes: Personal Values, Value Orientations, And Attitudes About Recycling As Antecedents Of Recycling Behavior. Journal of Business Research, 30, 1994, 58.

Mengüşoğlu, T. (1983). Felsefeye Giriș. Remzi Kitabevi, İstanbul

Milman, A., \& Kiparsky, M. (2020). Concurrent Governance Processes of California's Sustainable Groundwater Management Act. Society \& Natural Resources, 33(12), 1555-1566.

Nebot, A. C. (2021). Prosodic modulation as a mark to express pragmatic values: The case of mitigation in Spanish. Journal of Pragmatics, 181, 196-208.

Nevitte, N., Blais, A., Gidengil, E., \& Nadeau, R. (2021). Values and Beliefs. In Anatomy of a Liberal Victory (pp. 99-114). University of Toronto Press.

Ocak, A. Y. (1996). Türkiye'de ahilik araştırmalarına eleştirel bir bakış. I. Uluslararası Ahilik Kültürü Sempozyumu Bildirileri, Ankara: Kültür Bakanlığı Yayınları

Oğurlu, İ., Ahiliğin Çevre Ahlakı ve Eğitimine Bakan Yönleri Üzerine Bir Değerlendirme, Eurasian Academy of Sciences Social Sciences Journal, 2016 Volume: 8, S: 169 - 187

Ozata, M., \& Şener, E. (2019). Esnaf ve Sanatkârların Ahilik Değerlerine Sahip Olma Durumlarının Bazı Değişkenler Açısından Belirlenmesi: Kırşehir 
Hasan TUTAR

Örneği 1. Business and Economics Research Journal, 10(4), 945-958.

Özata, M., \& Şener, E. (2018). The Evaluation of The Tradesmen's and Craftmen's Levels of the Ownerships of Akhi-Order Values in Kırşehir. www. inglobe.org, 478.

Pala, A. (2007). Türk Kültür Tarihinin bir kaynağı olarak Burgazi Fütüvvetnâmesi. Türk Kültürü ve Hacı Bektaș Veli Araștırma Dergisi, 44

Pickles, D., King, L., \& De Lacey, S. (2017). Culturally construed beliefs and perceptions of nursing students and the stigma impacting on people living with AIDS: A qualitative study. Nurse education today, 49, 39-44.

Rindova, V. P., \& Martins, L. L. (2018). From values to value: Value rationality and the creation of great strategies. Strategy Science, 3(1), 323-334.

Robbins, S. P. (1992). Essentials of Organizational Behavior, Prentice-Hall, New Jersey. S.25

Rokeach, M. (1973). The Nature of Human Values, The Free Press, New York. S.5

Sadegül A. A., (2003) “Eğitim Yönetimi ve Degerler”, Değerler Eğitimi Dergisi, 1(1), s. 7-18.

Sağnak, M. (2005). İlköğretim Okullarında Görevli Yönetici ve Öğretmenlerin Değer Uyum Düzeyleri, Kuram ve Uygulamada Eğitim Bilimleri, Cilt. 5 , Sayı.l, s. 207-228, İstanbul, s. 209

Sancaklı, S. (2010). Ahilik ahlakının oluşumunda hadislerin etkisi. İnönü Üniversitesi İlahiyat Fakültesi Dergisi, 1(1), 1-18

Schwartz, S., \& Bilsky, W. (1987). Toward A Universal Psychological Structure of Human Values, Journal of Personality and Social Psychology, Vol. 53, No.3 s.551

Shobeiri, S. M. (2018). The Role of Social Networks on the Culture of the Teachers' Environmental Values and Beliefs: a case study of the telegram. Environmental Education and Sustainable Development, 6(2), 37-43.

Sison, M., Yu, M., Castillo-Carandang, N., UY, A., Villarante, K., Maningat, P., \& Cubillan, E. (2018). A qualitative study on the attitudes, behaviors, and beliefs of urban adult Filipinos on sunlight exposure: 6395. Journal of the American Academy of Dermatology, 79(3).

Sözen, E. (2017). Söylem (Belirsizlik, Mübadele, Bilgi/ Güç ve Refleksivite. İstanbul: Profil Kitap Yayıncılık (İnkılap Kitapevi Baskı Tesisleri).

Şahin, H. (2006). Selçuklular devrinde Ahiler. Anadolu Selçukluları ve Beylikler 
Dönemi Uygarlığı I. A. Y. Ocak (Ed.), Ankara: Kültür ve Turizm Bakanlığı Yayınları

Şahin, H. (2007). Osmanlı Devletinin kuruluş döneminde dini zümreler. Yayımlanmamış doktora tezi. Marmara Üniversitesi, Sosyal Bilimler Enstitüsü, İstanbul.

Tekin, M. (2006). Bir sosyal kontrol aracı olarak Ahilik ve toplumsal dinamikleri. Selçuk Üniversitesi İlahiyat Fakültesi Dergisi, 21, 219-235.

Thompson, L., \& Milter, R. G. (2018). CityLab: An Academic Business Capstone for the Urban Century. Business and Professional Ethics Journal.

Timuçin, A. (1994), Felsefe Sözlüğü, B.D.S. Yayınları, İstanbul, s.60.

Ulu, M. (2018). İlahiyat fakültesi öğrencilerinin psikolojik iyi oluşları ile değer yönelimleri arasındaki ilişki. Sakarya Üniversitesi İlahiyat Fakültesi Dergisi, 20(37), 183-215.

Umanailo, M. C. B., Umanailo, A. R., \& Umanailo, A. D. S. (2020). Functions of Values, Morals, Justice, Order and Community Welfare. Authorea Preprints.

Ünsür, A. (2020). Ahilik Sistemi Değerleri Yönetim ve Eğitimi. Değerler Eğitimi Dergisi, 18(39), 297-337.

Wiener, Y. (1988). Forms of Values Systems: A Focus on Organizational Effectiveness and Cultural Change and Maintenance, Academy of Management Review, V. 13, p. 545.

Witte, K. and M. A. A Meta-Analysis Of Fear Appeals: Implications For Effective Public Health Campaigns. Health Education \& Behavior, 27.5 (2000): 591-615.

Yiğit, İ. (2017). XVI. Yüzyll Türkiye'sinde Ahi Adlı Yerleşmeler. Journal of World of Turks/Zeitschrift für die Welt der Türken, 9(3).

Yüksel, Ö. (2006). Davranış Bilimleri, Gazi Kitabevi, Ankara, s: 100

Zhao, Y. (2021). The Pragmatic Values of Chinese-English Fuzzy Language in Communication.

Widdowson, H. G. (1973). An Applied Linguistic Approach to Discourse

Analysis. (Erişim Tarihi: 06.09.2021,

https://www.era.lib.ed.ac.uk/handle/1842/17734)

https://ungc.bilgi.edu.tr/tr/sss.html (Erişim. 09.09.2021)

https://www.globalcompactturkiye.org/(Erişim. 03.09.2021)

https://www.unglobalcompact.org/what-is-gc/mission/principles (Erişim. 
Hasan TUTAR

01.09.2021)

https://www.unglobalcompact.org/what-is-gc/mission/principles (Erişim.

04.09.2021)

https://www.unglobalcompact.org/what-is-gc/mission/principles (Erişim. 07.09.2021)

海洗

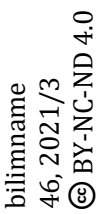

|188| 


\title{
AHİLİK DEĞERLERİ VE GLOBAL COMPACT ÍLKELERİ: ÖRTÜŞME VE AYRIŞMA NOKTALARI ÜZERİNE BİR ÇÖZÜMLEME
}

\author{
Hasan TUTAR ${ }^{\mathrm{a}}$
}

\section{Geniş Öz}

Değerler insanların tutum ve davranışlarına rehberlik eden ölçütlerdir. İnsanlar iş ve özel yaşamlarında tutum ve davranışlarına ölçüt olması bakımından değerlere ihtiyaç duyarlar. İnsanlar sosyal bir varlıktır ve değer insanlarla hatta tüm doğayla kurduğu ilişkiler sonucunda üretir. Çevresinde olup bitenler hakkındaki tutum ve davranışları ve onları değerlendirme biçimi insana iş ve yaşam değerleri kazandırır. İnsan çevresindeki olaylara tepki gösterdiğinde, onlar üzerinde birtakım değerlendirmelerde bulunur ve onlara bir değer atfeder. Değer, insanın herhangi bir olaya veya olguya verdiği anlam dizgeleri olarak işlev görür. Değerler kimi zaman insanın tercihine göre davranmasına ilişkin bir inanç olarak ifade edilirken, kimi zaman da "tercih ölçütleri” ya da "yaşam standartları" olarak görülebilir. Bu araştırmanın temel amacı fütüvvet geleneğinin etkisiyle ortaya çıkmış olan Ahilik değerleri ile bugün küresel değerler seti olarak sunulan Global Compact arasında karşılaştırma yaparak örtüşme ve ayrışa noktalarını belirlemektir. Araştırma iki farklı değerler dizgesinin karşılaştırılmasını esas aldığı için araştırmada nitel bir yöntem olan içerik çözümleme tekniğinden yararlanılacaktır. Bu amaçla araştırmada iki değerler dizgesinin temel değerlerini yansıtan metinlerin içerik çözümlemesi yapılarak ahilik değerleri ile global compact değerler dizgesinin hareket noktası karşılaştırmalı olarak analiz edilecektir.

Ne zaman değerlerden söz edilse akla ilk gelen birey ve onun iş ve özel yaşamıdır. Bu nedenle değerler, kişinin iş ve özel yaşamını düzenleyen norm koyucu ilkelerdir (Kağıtçıbaşı, 1980: 21). Bir insan veya toplum bir şeyi kendisine amaç edindiği zaman ona ulaşmanın koşullarını araştırır ve bu

a Prof., Abant İzzet Baysal University, hasantutar@ibu.edu.tr 
süreçte inanç, norm ve değer oluşturur. Bu inanç ve değerlerin kendini amacına ulaştırmasına yardım edeceğini düşünür. Bu aslında bir konu hakkında kesin bir karara sahip olmaktan ziyade ihtimale dayalı ve nesnel temelden yoksun bir inançtır. İnanç ve değerlerin objektif ve nesnel bir hal alıp kurumsallaşması, onların toplumsal düzleme yayılmasına bağlıdır (Milman, \& Kiparsky, 2020; Maaranen et al., 2019; Beck et al., 2018). Bu çerçevede ahilik değerleri toplumsal, ekonomik ve kültürel yaşama yön veren değerlerin toplumsallaşmasını ve kurumsallaşmasını sağlaması yönüyle büyük bir öneme sahiptir. Ahilik değerleri dönemi itibariyle toplumda Kant'ın ifadesiyle bir ahlak yasasının kurumsallaştırılmasına katkı sağlayan önemli bir işlev görmüştür (Aydın, 1991: 52). Ahilikte toplumsal, ekonomik ve kültürel her tür faaliyette her hâlükârda "ahlâk yasası"na göre hareket etme zorunluğu vardır. Bu tür bir inançta temel amaç; dürüstlük, doğruluk, adalet, asalet, güven ve erdem üzere bir yaşam sürmektir. Bu ilkelerin temel amacı toplumda ahlaka ve inanca dayalı bir yaşam sürmektir. Esasen "din" olgusunun temel hedefi de güzel ahlakın kurumsallaştırılmasıdır ki Ahilik'te tam olarak bunu yapmaya çalışmıştır.

Ahilik değerlerinin temel hedefi ekonomik olarak kalkınma ile birlikte, sosyal ve kültürel olarak gelişmedir (Özata, M., \& Şener, E. (2018). Global compact ise birleşmiş milletler örgütünün belirlediği 10 İlke çerçevesinde değerler dizgesi oluşturmayı ve tüm dünyada sadece çalışma değerlerini yaygınlaştırmayı amaçlamaktadır. Bu amaçla insan hakları, çalışma standartları, çevre ve yolsuzlukla mücadele alanlarında iş dünyasının temel sorumlulukları 10 ilke halinde belirlemiştir. Birleşmiş Milletler Global Compact 'in 10 İlkesi konuyla ilgili evrensel olarak kabul edilen ve seküler kaygılardan hareket eden Birleşmiş Milletler bildirgelerine dayanır (www.unglobalcompact.org). Arada bin yıldan fazla bir zaman ve ilkelerinin ve içeriğinin zenginliği ile ahilik değerleri ve global compact değerleri arasında karşılaştırmalı bir analiz yapmanın önemli ve fonksiyonel olacağ ileri sürülebilir. Araştırma aynı zamanda bu yöndeki literatürdeki boşluğun doldurulmasına da önemli katkı sağlayacaktır. Buna göre araştırmada "Birleşmiş Milletler Global Compact ve ahilik değerlerinin ayrışma ve örtüşme noktaları nelerdir" temel sorusunu cevaplandırmak amaçlanmıştır.

Sonuç olarak yukarıdaki ahilik değerler manzumesine bakınca bunların sadece ahilikle birlikte ortaya çıkan değerler dizgesi değil, Türk kültüründen ve İslam dininden kaynaklanan inanç ve değerler olduğu hemen göze çarpar. $\mathrm{Bu}$ düsturların İslam inancının toplumsal yaşama ilişkin kaidelerinin yanında Türk milletinin kültür kodlarının da önemli bir yeri vardır. Nitekim bu değerleri aynı inanç ve kültür köklerinden beslenen Ahmet Yesevînin 
Divanı-ı Hikmet ve Hünkâr Hacı Bektaş-ı Velînnin Makalât adlı eserinde bulmak mümkündür. Bu ilkelere çıkar, yarar, kazanç, kâr, rekabet, stok, faiz gibi kapitalist zihniyetle kirletilen iş ve mesleki yaşamın yanında hırsla ve doyumsuzlukla karartılan toplumsal yaşama karşı önemli bireysel ve toplumsal değerlerdir.

Ne pahasına olursa olsun satmak için üretmek düşüncesi, insanı hem fedakârlıktan hem de tüketim ahlakından uzaklaştırmaktadır. Egonun tatmini ile mutlu olmayı aynı sanan bir anlayış toplumsal değerleri aşındırmaktadır (Durak and Yücel, 2010). Toplumların yaşadığı, ahlaki ve içtimai problemlerin birçoğunun temelinde tamahkârlık, doyumsuzluk ve nefse düşkünlük gelmektedir. Ahiliğin eline, beline, diline hâkim; eli, sofrası ve kapısı açı, nefsinin arzularına kapalı insanı bugün için de bir prototip insandır. Benmerkezciliğin topluma verdiği zararların önlenmesi ve toplumsal huzurun sağlanması için bu insan tipine çok ihtiyaç vardır.

Günümüzde ahilik düşüncesi yaşanabilir mi?" sorusu akla gelmektedir. Kazanmadan yaşama, gereksiz tüketim, israf, para ile para kazanma, emeğin değersizliği, kullan at kültürü bir sosyal problem ise ahilik de bir çözümdür (Brenner: 1999; Arslan, 2015). Bilinçsiz tüketim, nitelikli insan yetiştirememe problemi, iletişim eksiklikleri, yapmacık ve yüzeysel ilişkiler, kalitesiz mal üretimi bir sorun ise her tür kalitesizliğin pabucunu dama atan ahilik bir çözümdür. Bitmeyen ihtiyaçlar, ihtiraslar, istekler, kendi kendine yetememe sorunu, başkasını düşünme yoksunluğu gibi problemler önemli toplumsal sorunlar ise özveriye, başkasının nefsini kendine tercih etme düsturuna dayalı ahilik değerleri çözümün bizzat kendisidir. Ahiliğin, müntesibine ahlaki yapı, sağlam bir karakter, dengeli bir hayat ve ölçülü davranışlar kazandıran anlayışı önemli bir çözümdür. Tek amacı daha çok kazanmak olan bu kapitalist insanın aç gözlülügü insanın ve çevrenin tahribi bakımından bir sorun ise kardeşliği, uhuvveti, tesanütü, almadan vermeyi ve kanaati ahlaki ilke sayan ahilik bir çözümdür.

Anahtar Kelimeler: Din Psikolojisi, Toplumsal değerler, Ahilik, Ahi Evran, global compact, çalışma değerleri, sosyal sermaye.

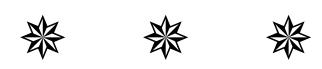

Teşekkür: 
Hasan TUTAR

Etik Kurul İzni gerekmemektedir.

\section{Katkı Oranı Beyanı:}

Yazar, makaleye başkasının katkıda bulunmadığını beyan etmektedir.

\section{3. Çıkar Çatışması Beyanı:}

Yazar, herhangi bir çıkar çatışması olmadığını beyan etmektedir.

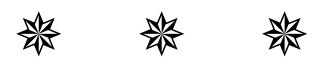

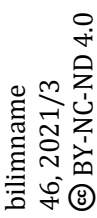

|192| 